FACTA UNIVERSITATIS

Series: Physical Education and Sport, Vol. 17, No 2, 2019, pp. 353 - 369

https://doi.org/10.22190/FUPES190731032S

Research article

\title{
THE TREND IN THE NUMBER OF PARTICIPANTS FROM SERBIA IN THE BELGRADE MARATHON FROM 2007 TO 2019: THE EFFECT OF GENDER AND AGE
}

\author{
UDC 796.422.16:57.017.5(497.11) “2007/2019”
}

\section{Stanimir Stojiljković, Milan Matić, Ljubica Papić}

Faculty of Sport and Physical Education, University of Belgrade, Belgrade, Serbia

\begin{abstract}
The aim of the research is to analyze the trend in the number of participants in the Belgrade Marathon in the period 2007-2019: total, by gender and age categories, with a special reference to participants from Serbia. Using linear regressions, it was found that the total number of participants, both from Serbia and abroad, significantly increased; total number of male and female participants, both from Serbia and abroad, significantly increased; the number of women is growing more than men every year, especially inthe sample of participants from Serbia; the number of participants by age categories of 5 years, for women and men from Serbia increased to the age group of 3035 years, and then slowly decreased; the percentage of men and women in the 30-39 age category is increasing; the proportion of female seniors and female veterans is increasing. Statistically significant decreases: percentage of men in the 50-59 age category; percentage of male veterans. The percentage of male seniors didnot change. It can be concluded that the number of participants in the Belgrade Marathon, especially participants from Serbia, is increasing significantly, with a trend that exceeds many marathons in the world. The number of women is lower than in most marathons in the world, but the number of women from Serbia is increasing significantly compared to the number of men, which is in line with world trends. The number of male veterans is decreasing, which is different from most marathons in the world.
\end{abstract}

Key words: Running, Gender Differences, Regression Models

Received July 31, 2019/ Accepted September23, 2019

Corresponding author:Milan Matić

University of Belgrade, Faculty of Sport and Physical Education, St. Blagoja Parovića 156, 11000 Belgrade, Serbia

Phone: +381 113531000 •E-mail: milan.matic@fsfv.bg.ac.rs

(C) 2019 by University of Niš, Serbia | Creative Commons License: CC BY-NC-ND 


\section{INTRODUCTION}

According to the World Health Organization (WHO), the lack of physical activity is a leading risk factor for human mortality (WHO, 2009). Regular physical activity has been shown to reduce mortality risk and extend life expectancy (Williams, 2009). Aerobic activity has a major positive impact on the psychological and sociological aspects of health, and thus on quality of life in general (Lee et al., 2014).

Running is a popular form of physical activity aimed at a healthy lifestyle. It is a natural form of movement, an accessible, effective and relatively inexpensive form of exercise (Stojiljković, 2005). Long-term running develops cardiovascular (general) endurance (Mustedanagić, Bratić, Milanović, \& Pantelić, 2016), which is a preventive agent against the onset of cardiovascular diseases and high blood pressure. Sport training leads to the emergence of a "sports heart": morphological and functional adaptations of the heart (hypertrophy and dilatation of the heart, with accompanying angiogenesis and slow cardiac output), which in turn result in an increase in the efficiency and economy of cardiac work (Milutinović et al., 2019).Running (with brisk walking) is an indispensable tool in all programs of tackling obesity and metabolic problems, as it is a cyclic activity involving large muscle groups, with a lot of calories consumed (Stojiljković, Mitić, Mandarić, \& Nešić, 2012).

The results of a meta-analysis of numerous scientific studies confirm that long-term running effectively provides positive effects on body weight, body fat percentage, resting heart rate, maximum oxygen consumption, triglycerides and HDL cholesterol in previously inactive adults, and that health effects are greater for those who train longer (Hespanhol Junior, Pillay, van Mechelen, Verhagen, 2015).

In the last few decades, there has been a steady increase in the number of participants in the races in the world, at so called long runs - races at $5 \mathrm{~km}$ and $10 \mathrm{~km}, 21,097 \mathrm{~km}$ (half marathon), 42,195km (marathon) and longer. The marathon is currently the main focus of attention, as it is the longest running discipline in major athletics (Olympic Games and World Championships). The number of marathon runners in the world has also been increasing over the last few decades, although in recent years there seems to be a mild stagnation. In the US, the number of people who ran the marathon in 1976 was about 25,000, and from 2010 to 2016, it was constantly above 500,000, with the highest number reached in 2014 - around 550,000 (https://www.runningusa.org/RUSA/Research / Recent_Reports / Marathon_Report).

With the increasing number of participants in marathon races, the interest of researchers in studying participation trends and results, the demographic characteristics of participants, and the factors that influence marathon running success increased as well (Jokl, Sethi,\& Cooper, 2004; Coyle, 2007; Trappe, 2007; Noakes, 2003).

The marathon is one of the long-term endurance sports. Elite runners finish the marathon in just a little over 2 hours, and recreational runners (who make up a population of about $99 \%$ of large marathon runners up to 50,000 people) often need two to three timesas much. The time limit in the marathon is usually 5 or 6 hours (those who do not finish in the scheduled time do not have a result, i.e., it is considered that they did not finish the race).

Running a marathon requires regular physical exercise, first of all, long running, but running a marathon in addition to training requires a healthy lifestyle. Research results have shown that runners who run over $30 \mathrm{~km}$ per week are at a lower risk of injury in the marathon, compared to runners who run less than $30 \mathrm{~km}$ per week (Rasmussen, Nielsen, Juul, \& Rasmussen, 2013). There is evidence that, compared to the rest of the population, 
marathoners are less likely to experience poor life habits such as smoking, obesity and lack of physical activity (Leyk et al., 2010). Training for a marathon and running a marathon also brings some psychological benefits, though this area is under-explored (Zabala, Rueda, de la Llave Rodríguez, 2009; Nikolaidis, Rosemann, \& Knechtle, 2018b).

The Belgrade Marathon has been organized since 1988 and has the longest tradition in Serbia among marathon races that are held regularly every year. The length of the track in the first race was slightly longer than the half marathon distance - $23 \mathrm{~km}$ (Juhas \& RepićĆujić, 2016, p. 45). The following year the race took place overtwo distances: a half marathon and a marathon. The marathon track was poorly measured, so the distance was actually a few kilometers longer - 46,7km (Juhas \& Repić-Ćujić, 2016, p. 51). From 1990 to the present, the marathon is organized on a precisely measured track, on weekends in the spring, earlier in May, and for many years the time it is heldhas settled tothe end of April. The route of the Belgrade Marathon has been changed several times over the course of its 32 years of history, most recently in 2017. The Belgrade Marathon is a large one-day event that gathers thousands of participants, and within the same day, there are three races at different distances: the $5 \mathrm{~km}$ - fun run, half marathon and marathon.

After the 2019 race, the Belgrade Marathon Company signed an agreement with the Abbott World Marathon Majors, under which the Belgrade Marathon became part of the famous World Marathon Majors series (quality marathons organized in large cities around the world, which have a long tradition and a large number of participants). The Belgrade Marathon 2020 will be a part of the series as the only event of this kind in the wider region. It is a new system of ranking participants in the categories over 40 who, in relation to their achieved results in a number of selected marathons in the world (among which is now the Belgrade Marathon), qualify to participate in the 2021 Masters. The name of the city of the marathon where the 2021 World Cup will be held will soon be known (33. Beogradski maraton deo World marathon Majors serije, 2019).

With the increasing popularity of long-distance running, with the largest number of recreational runners, the number of women and veteran runners (over 40 years of age) running the marathon has also increased (Burfoot, 2007). Research results show that the number of older marathon runners is increasing at a higher rate than in the younger categories (Jokl et al., 2004). Also, men running marathons are on average older and faster than the women, but the number of women running marathons are increasing more than that of the men every year, so the percentage of women who run marathons is increasing (Nikolaidis, Rosemann, \& Knechtle, 2018a; Vitti, Nikolaidis, Villiger, Onywera, \& Knechtle, 2019). With the increase in the number of women running marathons, in recent decades there has been a trend of decreasing differences in results between women and men, with elite runners, but even more with recreational athletes (Knechtle, Di Gangi, Rüst, $\&$ Nikolaidis, 2019). Research results show that marathon runners experience a significant drop in marathon results after 55 years of age, suggesting regular physical exercise (Leyk et al., 2009). Lately, older people have been running the marathon, up to the age of 90.

Between 2004-2011, an average of 17 women and 114 men over the age of 75 attended four of the 6 largest marathons in the world (Berlin, New York, Chicago and Boston) each year,without significant changes in the number of participants older than 75 years participating inthose events (Ahmadyar, Rüst, Rosemann, \& Knechtle, 2015).

The very fact that a World Marathon Championship for Veterans will be organized in two years (by age categories of 5 years each) indicates that the importance of recreational runners, especially in the categories over 40 , is recognized in the world for the success of 
these significant events. In this research, special attention will be paid to the number of participants in particular age categories.

There are not many papers in Serbia published by localresearchers on the marathon. There are hardly any works on the participants of the Belgrade Marathon during the more than 30 years of its history. By reviewing the literature,only one paper on sociodemographic characteristics and individual variables of participants' training at the Belgrade Marathon could be found, published in 1992 (Mitić \& Stojiljković).

Hence, marathon runners are an interesting topic to study. This paper analyzes the trend of the number of participants in the Belgrade Marathon in the longest distance (marathon), both in total and by gender and age categories, over the last 12 years: from 2007 to 2019. Particularly, the participants from Serbia have been analyzed in detail since 2007 competitors from Serbia act as citizens of the Republic of Serbia.

The aim of the research is to analyze the trend in the number of participants in the Belgrade Marathon in the period from 2007 to 2019: total, by gender and age categories, with special reference to participants from Serbia.

\section{METHODS}

\section{Sample of participants and variables}

The results of the marathon distance races at the Belgrade Marathon in the period from 2007 to 2019, which are on the official site of the Belgrade Marathon, were used as a database for this research.

Participants' data, available for races during the analyzed period and used for the purposes of this research, are: race year, name, gender, age, country for which the competitor competes, placement, and goal result.

In total, 6297 results were analyzed in the paper, from participants who completed the marathon race in the scheduled time, during the last thirteen marathons held in Belgrade. In analyzing the data, several problems had to be solved, the first of which stemmed from a change in the rules, and the others were of a methodological nature, the source being that the race organizer has repeatedly changed the type, number and method of displaying data from the competition over the years:

- In the 2007 race, the time limit for completing the race was 5 hours, and from 2008 until today, the time limit has been increased to 6 hours, which initiates a number of participants (the slowest) to register and later finish the race. The results from 2007 were included in the analysis, noting that it is realistic to assume that if the time limit was 6 hours that year, the number of those who finished the race would be about $20 \%$ higher (based on data from 2008 to 2019). Also, in the last few years, those who have completed the marathon are also those who have done it in more than 6 hours. To make a comparison with the previous period, only participants who completed the race in less than 6 hours were included in the analysis;

- For 2012 there is no data on the year of birth of the competitors. Therefore, an attempt was made to find the year of birth for the competitors from Serbia from the data from the previous or subsequent years (the entire period 2007-2019 was studied). This attempt was abandoned because it was impossible to find data for a large number of the participants who ran the race only in 2012; 
- In the period 2007-2011, the men and women were on a shared list with no indication on gender, so for research purposes they were sorted according to gender based on their names;

- In the official results from the Belgrade Marathon, age categories appear only from 2016, so that all the participants under 35 are classified as Adults, and only from the age of 35 upwards were the participants categorized into age categories of 5 years each. For the purposes of this research, in the period 2007-2015, the participants were classified into age categories of 5 years each (except for the results from 2012, where there is no data on the year of birth), and in the period 2016-2019, the Adult category was classified into four categories with a smaller age range: up to 20; 2024, 25-29 and 30-34. Although there is no consensus in the literature as to what age separates seniors from sports veterans, it is defined for the purposes of this research that veterans are persons aged 40 and over, as suggested by Lepers \& Cattagni (2012). It should be noted that some authors propose that the limit for the category of veterans (master) should be 50 (Jokl et al., 2004);

- There was interest in analyzing the number of participants who started but did not finish the race. However, due to lack of adequate data, this idea was abandoned. From year to year, after the placement and the results of the participants who finished the race, the official lists contains names of those who did not finish the race. However, different labels are used, wherefrom it is not possible to determine for sure which of the participants started the race, but did not finish (who dropped out during the race or did not finish in the scheduled time); who finished the race, but was disqualified for not passing all the checkpoints; who signed up for the race, but didnot show up at the start. In addition, the list of participants in the 2015 marathon ended with the last participant that successfully completed the marathon, and there is no record of those who failed.

\section{Statistical analysis}

The results were processed by a descriptive and regression statistical analysis. From the space of descriptive statistics, central (arithmetic mean) and dispersion parameters were calculated: standard deviation (absolute measure of dispersion) and coefficient of variation (relative measure of dispersion).A linear regression analysis was used to estimate the trend in numbers: all of the participants who ran the Belgrade marathon, the men who ran the Belgrade marathon, and the women who ran the Belgrade marathon in the period 2007-2019. Linear regression was also used to determine the trend of the ratio of men to the number of women and the number of persons from Serbia who ran the Belgrade marathon by age categories of 10 years, as well as by categories of seniors and veterans, both in absolute numbers and as a percentage of the total number, in the period 2007-2019. For all comparisons, the level of statistical significance was set at the level $\mathrm{p}<0.05$, and data processing was performed by the use of software SPSS 21.0 (SPSS Inc, Chicago, IL, USA) and Office Excel 2010 (Microsoft Corporation, Redmond, WA, USA). 


\section{RESULTS}

\section{The total number of participants at the Belgrade Marathon in the period from 2007 to 2019}

Table 1 shows the number of participants who ran the Belgrade Marathon by year, in the period 2007-2019. For each year, the total number of participants, the number of men and women and their numerical ratio are presented, as well as the same data on a sample of participants from Serbia and participants from other countries.

Table 1 Participants who ran the Belgrade Marathon from 2007 to 2019

\begin{tabular}{lrrrrrrrrrrrrr}
\hline & \multicolumn{1}{c}{ All } & \multicolumn{1}{c}{ Serbia } & \multicolumn{4}{c}{ Other } \\
\hline Year & Total & Men Women & $\begin{array}{r}\text { M/W } \\
\text { ratio }\end{array}$ & Total & Men & Women $\begin{array}{r}\text { M/W } \\
\text { ratio }\end{array}$ & Total & Men & $\begin{array}{r}\text { Wome } \\
\text { n }\end{array}$ & $\begin{array}{r}\text { M/W } \\
\text { ratio }\end{array}$ \\
\hline 2007 & 177 & 157 & 20 & 7.85 & 81 & 76 & 5 & 15.20 & 96 & 81 & 15 & 5.40 \\
2008 & 168 & 156 & 12 & 13.00 & 108 & 105 & 3 & 35.00 & 60 & 51 & 9 & 5.67 \\
2009 & 285 & 253 & 32 & 7.91 & 134 & 125 & 9 & 13.89 & 151 & 128 & 23 & 5.57 \\
2010 & 202 & 178 & 24 & 7.42 & 142 & 128 & 14 & 9.14 & 60 & 50 & 10 & 5.00 \\
2011 & 276 & 250 & 26 & 9.62 & 159 & 149 & 10 & 14.90 & 117 & 101 & 16 & 6.31 \\
2012 & 290 & 259 & 31 & 8.35 & 205 & 186 & 19 & 9.79 & 85 & 73 & 12 & 6.08 \\
2013 & 322 & 294 & 28 & 10.50 & 235 & 216 & 19 & 11.37 & 87 & 78 & 9 & 8.67 \\
2014 & 479 & 432 & 47 & 9.19 & 294 & 276 & 18 & 15.33 & 185 & 156 & 29 & 5.38 \\
2015 & 605 & 535 & 70 & 7.64 & 407 & 365 & 42 & 8.69 & 198 & 170 & 28 & 6.07 \\
2016 & 738 & 661 & 77 & 8.58 & 442 & 398 & 44 & 9.05 & 296 & 263 & 33 & 7.97 \\
2017 & 896 & 780 & 116 & 6.72 & 603 & 528 & 75 & 7.04 & 293 & 252 & 41 & 6.15 \\
2018 & 880 & 751 & 129 & 5.82 & 553 & 480 & 73 & 6.58 & 327 & 271 & 56 & 4.84 \\
2019 & 979 & 817 & 162 & 5.04 & 611 & 524 & 87 & 6.02 & 368 & 293 & 75 & 3.91 \\
\hline Sum & 6297 & 5523 & 774 & & 3974 & 3556 & 418 & & 2323 & 1967 & 356 \\
Ave & 484.38 & 424.85 & 59.54 & 8.28 & 305.69 & 273.54 & 32.15 & 12.46 & 178.69 & 151.31 & 27.38 & 5.92 \\
St.Dev & 298.77 & 252.31 & 48.18 & 2.05 & 194.56 & 166.11 & 29.21 & 7.54 & 108.72 & 90.02 & 20.05 & 1.25 \\
CV & 61.68 & 59.39 & 80.93 & 24.73 & 63.65 & 60.73 & 90.85 & 60.52 & 60.84 & 59.49 & 73.2121 .14 \\
\hline
\end{tabular}

Table 1 shows that the Belgrade Marathon Belgrade Marathon finished about 485 participants per year, of which about 425 were men and 60 were women. High coefficients of variation indicate that the annual deviation from the average number of participants over the whole period was large, and is similar when looking at sub-samples of participants from Serbia and participants from abroad. On average, approximately 8.3 times more men than women managed to run the marathon (for this value, the coefficient of variation is small, meaning that the ratio of the number of male and female participants was relatively constant over the studied period). For the participants from Serbia, the ratio of the number of men and women is even more unfavorable for the women: about 12.5 times more men than women managed to run a marathon a year and the range was between 35:1 and 6:1.

In the period from 2007 to 2019 , a total of 6297 participants completed the race at the Belgrade Marathon in the scheduled time (Figure 1). $87.7 \%$ were men and $12.3 \%$ were women. The total number of participants from Serbia (SRB) was $63.1 \%$ and $36.9 \%$ were foreigners (STR). Among the participants from Serbia $89.5 \%$ were men and $10.5 \%$ were women, and among foreign participants $84.7 \%$ were men and $15.3 \%$ women. 


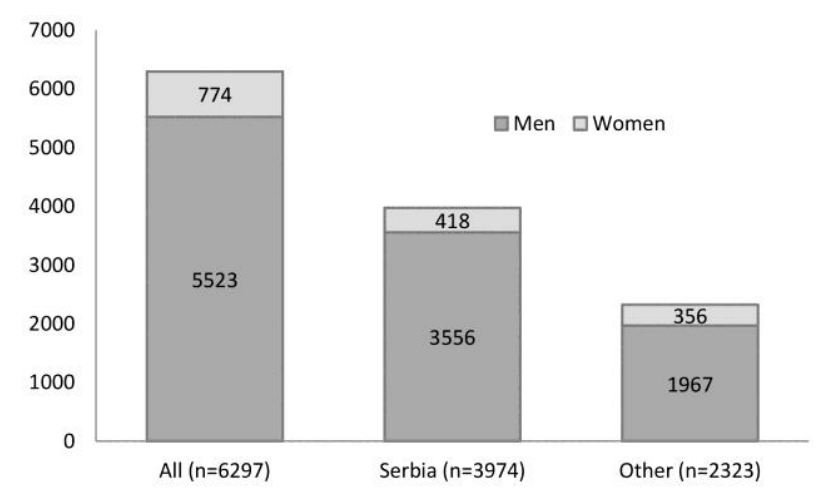

Fig. 1 Number of participants who ran the Belgrade Marathon from 2007 to 2019

Figure 2 shows the number of participants by year and the model and linear regression formulas, which shows how the number of participants changed by year in the observed period, both in the total sample and in particular on the sample of participants from Serbia and participants from abroad.

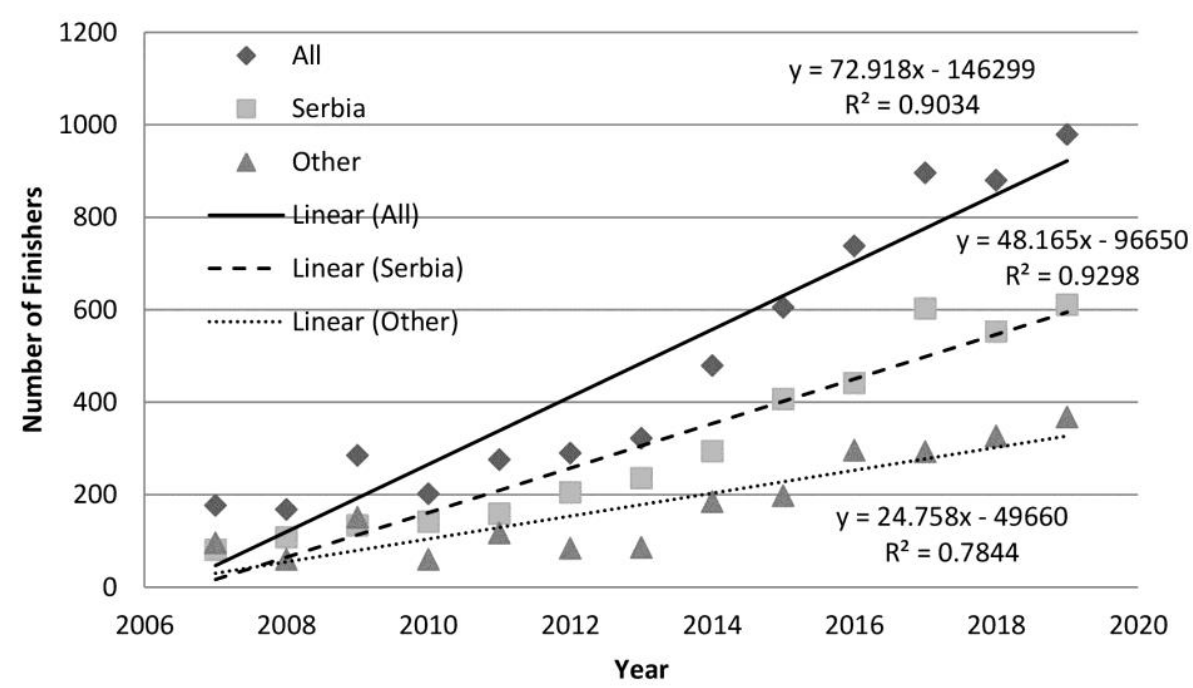

Fig. 2 Trend in the number of participants who ran the Belgrade marathon from 2007 to 2019

High values of the coefficient of determination $\left(\mathrm{R}^{2}\right)$ on the total sample and subsamples indicate that the linear regression models shown are very reliable (for all three models, $\mathrm{p}<0.001$ ), that is, a very large percentage of the relationship between the number of participants and the year of marathon maintenance is explained by the models shown (about $78 \%$ on the sample of participants from abroad, $90 \%$ on the total sample, and as much as $93 \%$ on the sample of participants from Serbia). From the formulas of the linear models shown in graph 2, it can be seen that in the studiedperiod, the total number of marathon participants increased statistically significantly, with an average of 73 participants per year, of which on average 48 were from Serbia and the other 25 were from abroad. 
The linear models presented also predicted the number of participants in the coming period, on the basis of which it was determined that if such trends continue, as early as 2020, the Belgrade Marathon could run a total of 1000 participants, the number of participants from abroad will reach 500 in 2026, and over 1000 participants from Serbia will run the BG marathon in 2028 (results not shown).

Figure 3 shows the number of male participants by year and the models and linear regression formulas that show how the number of men changed by year over the studiedperiod, both in the total sample and in particular in the sample of men from Serbia and men from abroad.

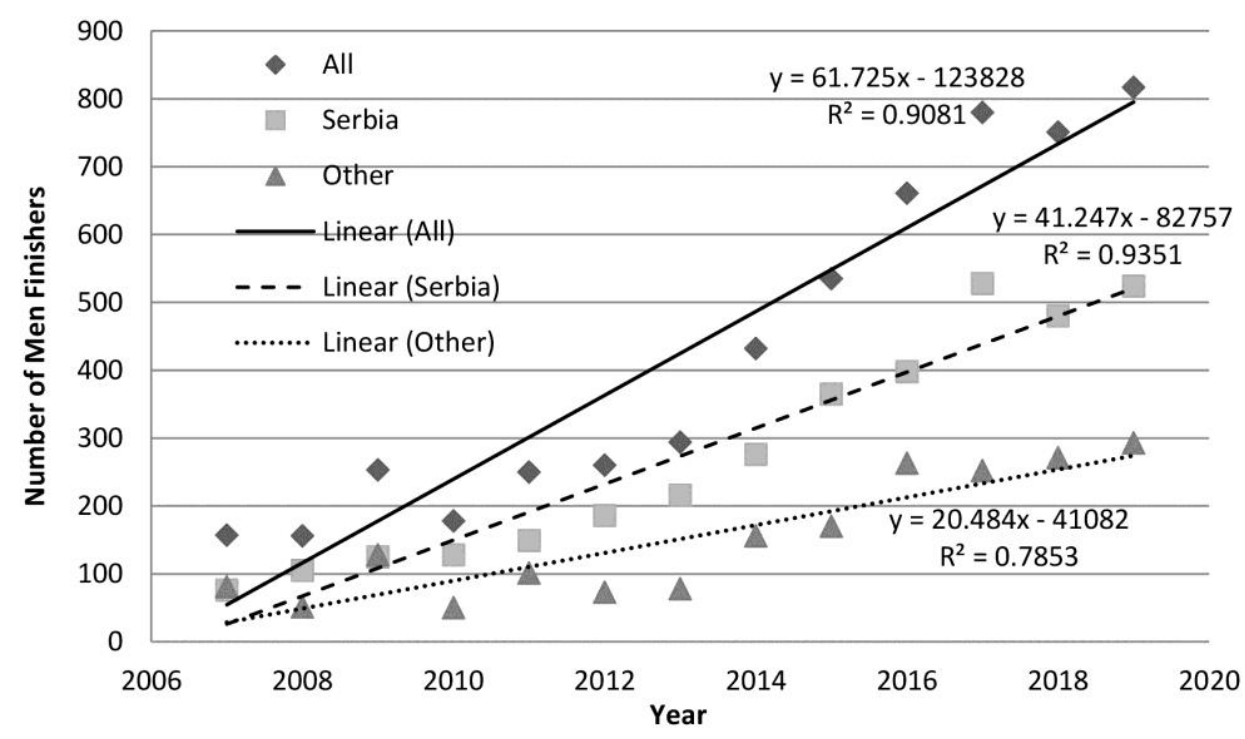

Fig. 3 Trend in the number of men who ran the Belgrade marathon from 2007 to 2019

High values of the coefficient of determination of the total sample of men and subsamples indicate that the linear models shown are very reliable (for all three models $\mathrm{p}<0.001$ ), that is, a very large percentage of the relationship between the number of participants and the year of marathon maintenance is explained by the models shown. The reliability of all three models in the male sample is almost identical to the models obtained in the total sample, which is logical because in the total sample, men represent almost $88 \%$. From the formulas of the linear models shown in Figure 3, it can be seen that in the studiedperiod, the total number of male marathon participants increased statistically significantly, with an average of 62 participants per year, of which on average 41 men were from Serbia and the rest were men from abroad.

Figure 4 shows the number of women participants by years and the linear regression models and formulas that present how the number of women changed by year in the studiedperiod, both on the total sample and on the sample of women from Serbia and women from abroad. 


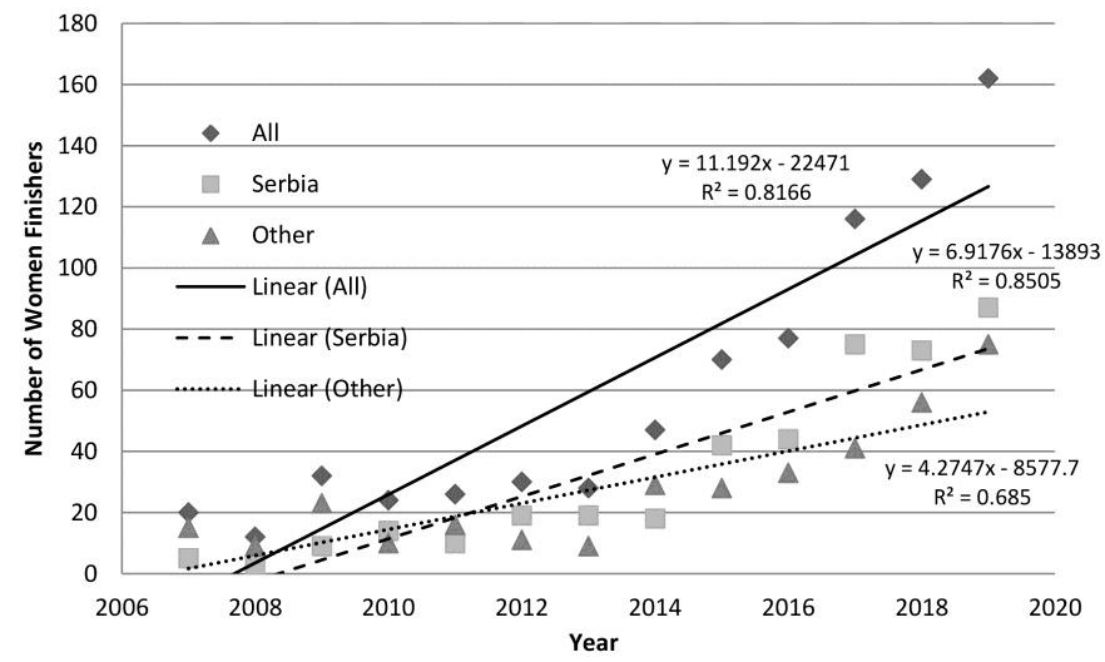

Fig. 4 Trend in the number of women who ran the Belgrade marathon from 2007 to 2019

The values of the coefficients of determination on the total sample of women and subsamples, although slightly lower than for the men, indicate that the linear models shown are very reliable (for all three models $\mathrm{p}<0.001$ ), that is, a very large percentage of the relationship between the number of participants and the year of the marathon is explained by the models shown. From the formulas of the linear models shown in Figure 4 , it can be seen that, over the studied period, the total number of female marathon participants increased significantly, with an average of 11 participants per year, of which on average 7 were from Serbia and four were from abroad.

Although it was noted that linear regression models in both men and women show a statistically significant increase in the number of participants from year to year, the absolute numbers show that the number of women who ran the Belgrade Marathon in the mentioned period is far smaller than the number of men. Therefore, it was interesting to determine whether the increase in the number of participants differs between men and women, that is, whether the relative increase is greater for men or women (or no statistically significant difference between them). Figure 5 shows the relative ratio of the number of men to the number of women and linear regression models for the total sample and for the sample of participants from Serbia. The linear regression model for the sample of participants from abroad was quite unreliable $(p=0.841)$ and therefore not shown in the figure.

The linear models show a negative trend in the number of men compared to the number of women who run the marathon, both for the total sample and even more for the sample of participants from Serbia. It can be concluded that the number of women is growing faster than the number of men from year to year, especially for the sample of participants from Serbia, and slightly less for the total sample (for both models it is $\mathrm{p}<0.05)$. For the participants from Serbia in the first years in the analyzed period, there were about 20 men who ran the marathon to each woman who ran the marathon, while in recent years this ratio has changed for the better in favor of the women, so that now, for approximately every 6 men, there is one a woman who runs a marathon. 


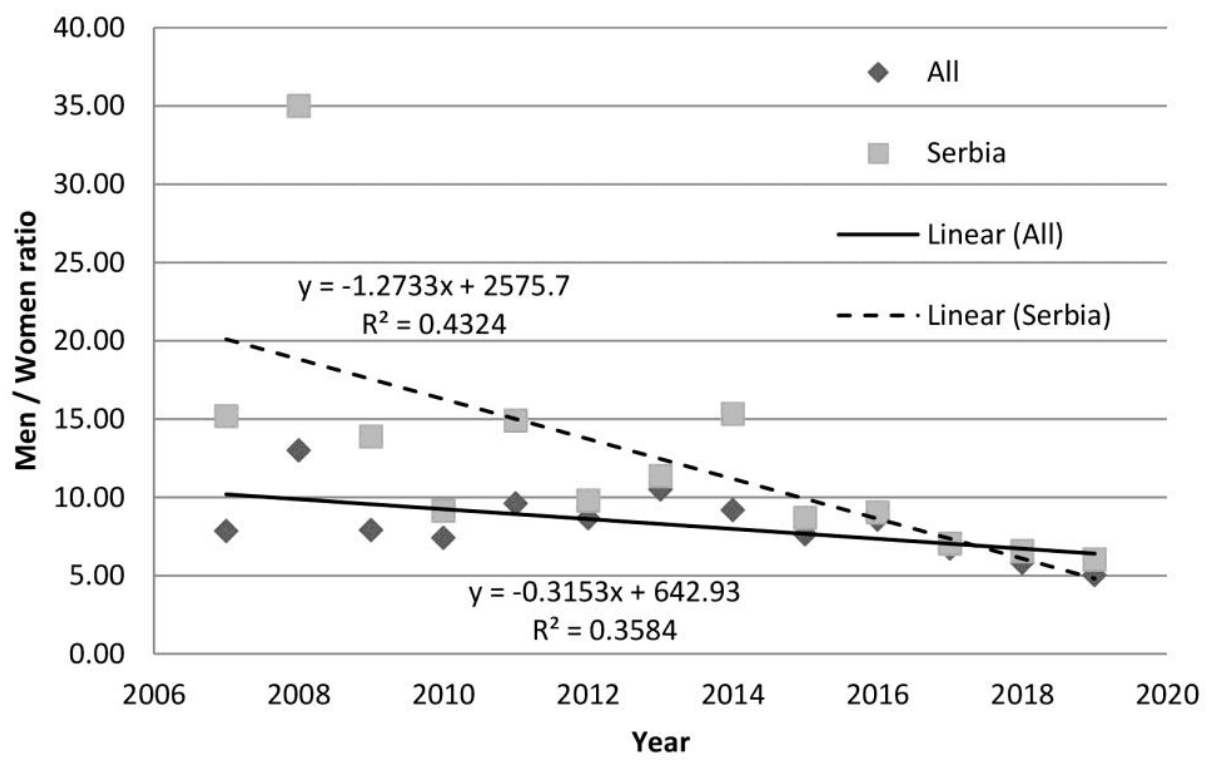

Fig. 5 Trend in the ratio of men to women in the period from 2007 to 2019

\section{Participants from Serbia in the Belgrade Marathon from 2007 to 2019by gender and age,}

The following analyzes the ages of marathoners from Serbia (3766 in total), on samples of men and women. Figure 6 shows the distribution of all the women (398 in total) and men (3368 in total) from Serbia who ran the marathon from 2007 to 2019 (missing data from 2012, not available), by age group of 5 years.

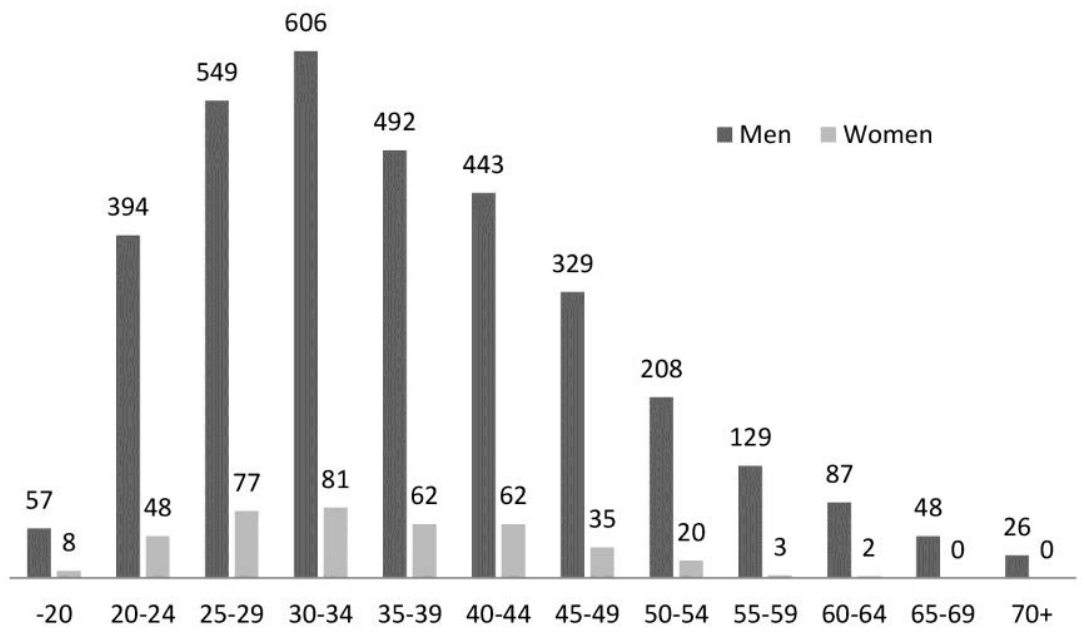

Fig. 6 Participants from Serbia in the Belgrade Marathon from 2007 to 2019, in 5 year age groups that finished the race 
Despite the fact that the number of men who have run a marathon is much higher than the number of women in each category, Figure 6 shows that the number of participants by age categories in both women and men rises to the age group 30-34 which contains the largest number of those who ran the marathon, which then slowly declined.

The ratio of the number of men to the number of women in each age category shown in Figure 6 slightly increases from approximately 7: 1 in the category of up to 20 years, up to 10: 1 in the category of 50-54, and then jumps sharply into the next two categories to as many as $43: 1$. The linear regression analysis showed a statistically significant trend of increasing the number of men relative to the number of women, observed from the younger to the older categories $\left(\mathrm{R}^{2}=0.54 ; \mathrm{p}<0.05\right)$. It can be concluded that the number of women who finished the Belgrade Marathon in the period from 2007 to 2019 in the older categories is even lower then number of men, contrary to the younger categories. This is especially pronounced in categories of over 55, where there are hardly any women.

If studied over the decades (up to 20 years, 20-29, 30-39, etc.), it can be observed in both women and men that the largest number of participants belongs to the age range of 30-39: 1098 men (32.6\% of all the men) and 143 women (35.9\% of all the women).

When all the participants fall into two age categories: seniors (under 40) and veterans (over 40); it can be calculated that the category of seniors belongs to 2098 men $(62.3 \%)$ and 276 women $(69.3 \%)$, while the veteran category belongs to 1270 men $(37.7 \%)$ and 122 women $(30.7 \%)$. In the total sample of participants from Serbia (women and men together), 2374 participants (63\%) are seniors, while $1392(37 \%)$ belong to veterans.

In relation to the age categories of the participants, it is interesting to investigate whether the positive trend in the number of participants, which was observed in the sample of marathon participants from Serbia, both in total and in men and women separately (see Charts 2, 3 and 4), can also be observed and for certain age categories of men and women. For these purposes, the men were divided into five age categories (up to 30 years of age, 30-39, 40-49, 50-59, and 60 and over), and the women into four categories (up to 30 years of age, 30-39, 40-49 and 50 and older). Models of linear regression were done for each of the above age categories and it was found that in each of them, both for the men and women, a high coefficient of determination was recorded $\left(R^{2}=0.71-0.84\right.$ in women in individual categories and 0. 84-0.96 in men). This clearly indicates the high reliability of the model, and it can be concluded that the number of women and men participating in the BG marathon, in all age categories, has increased statistically significantly from year to year, in the period from 2007 to 2019 ( $<<0.001$ for all models).

Another interesting question was: Does the positive trend of participation in the BG marathon, recorded for all age categories of women and men, differ between individual age categories, i.e., are there age categories in which the number of participants increases faster than in others? For these purposes, the number of female and male participants in individual age categories was expressed as a percentage of the total number of participants in that year (total women and men), and linear regression models were calculated for the values thus obtained. The models obtained were in most cases unreliable $(p \geq 0.05)$ and were not shown. Figure 7 shows the linear regression models for two age categories of men and one category of women, with statistically significant changes from 2007 to 2019. 


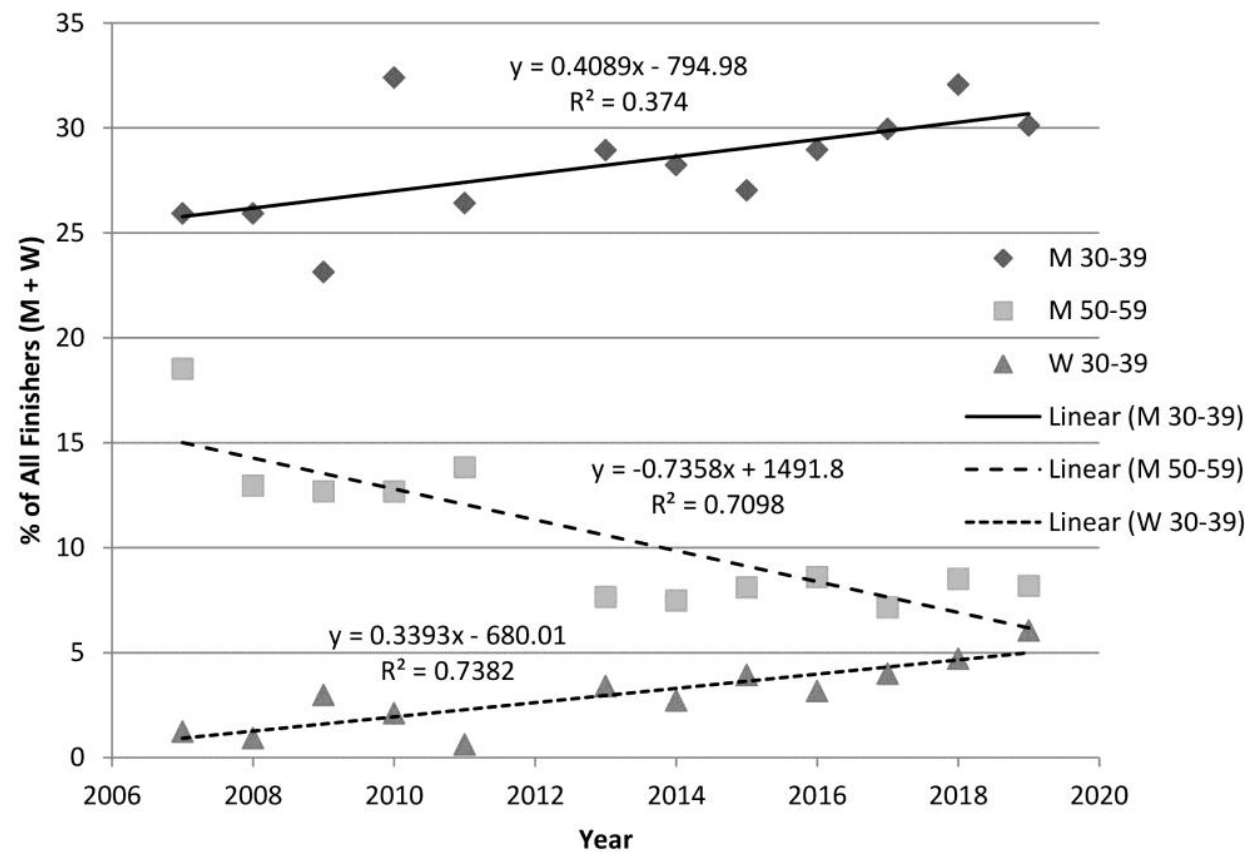

Fig. 7 Trend of the number of men and women from Serbia who ran the Belgrade Marathon, by age categories, as a percentage of the total number of the participants

Figure 7 shows that in the studied period the percentage of men in the category of 30 39 years $(p<0.05)$ increases statistically, the percentage of men in the category 50-59 years $(p<0.001)$ decreases statistically, and the percentage of women in the 30-39 year category $(p<0.001)$ increases statistically. It can be concluded that, although in the studied period the number of men and women in all age categories increases when we look at absolute values, when we look at percentage values, the situation is slightly different: only the percentage of men and women in the 30-39 age category increases statistically significant and only the percentage of men in the 50-59 age category declines significantly.

To get an even more transparent picture of the impact of age on the number of participants in the Belgrade Marathon from 2007 to 2019, a linear regression analysis for seniors (under 40 years) and veterans (40 and over) was performed for men and women from Serbia, both for absolute values (results not shown in the figure) and as a percentage of the total (Figure 8).

In absolute terms, as expected from the results obtained on the total sample of men and women from Serbia, the number of seniors and veterans in men and women increases statistically significant: all four models have high coefficients of determination and statistical significance $\left(\mathrm{R}^{2}\right.$ ranges from $0.78-0.94$, and for all models is $\left.\mathrm{p}<0.001\right)$. When viewed in relative terms, the situation is different (Figure 8): the percentage of female seniors increases by about $0.45 \%$ per year $(\mathrm{p}<0.01)$ and female veterans increases by about $0.26 \%$ per year $(p<0.05)$; but statistically, the percentage of male veterans decreases by about $0.72 \%$ per year $(p<0.05)$. Male seniors make up, on average, about 
$55 \%$ of all the participants from Serbia and have undergone no statistically significant changes (results not shown in figure).

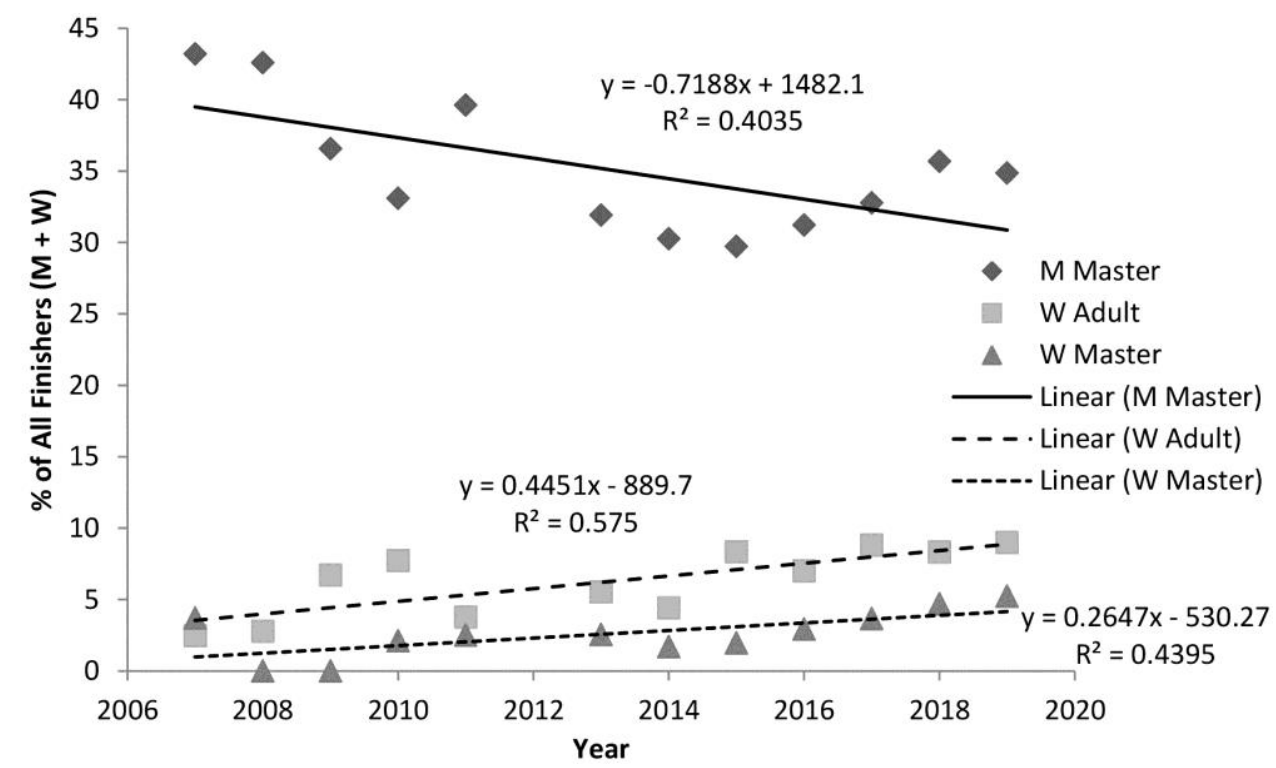

Fig. 8 Trend in the number of seniors and veterans, men and women from Serbia, who ran the Belgrade Marathon as a percentage of the total number of the participants

\section{DISCUSSION}

Total number of participants in the Belgrade Marathon in the period from 2007 to 2019

In the studied period, the number of participants in the Belgrade Marathon increased statistically significantly from various aspects: the total number of all participants, especially participants from Serbia, increased, the number of men and the number of women, especially women from Serbia, increased.

In terms of the number of participants, the Belgrade Marathon still cannot be compared to the big marathons in the world. In 2007, the Belgrade Marathon was run by a total of 177 participants (157 men and 20 women), while the same year the Chicago Marathon was run by 28,815 participants (16,945 men and 11,870 women) (Chicago Marathon results, 2007). The 2019 Belgrade Marathon was run by a record 979 participants (817 men and 162 women), while the 2018 Chicago Marathon was run by44.584 participants (23.934 men and 20.650 women) (Chicago Marathon results, 2007) and the New York Marathon as many as 52,706 participants $(30,581$ men and 22,125 women) (TCS New York City Marathon, 2018). However, the number of participants in the Belgrade Marathon increased 5.5 times $(553 \%)$, and the number of participants in the Chicago Marathon did not double. The number of marathon runners in New York for 16 years, between 1983-1999, increased by “only" 119\%: from 14,546 to 31,791 (Jokl, Sethi, \& Cooper, 2004). It can be concluded that 
the number of participants in the Belgrade Marathon has an exceptionally high growth rate. If such trends continue, as early as 2020, the Belgrade Marathon could be run a total of 1,000 participants, the number of participants from abroad will reach 500 in 2026, and over 1,000 participants from Serbia will run the Belgrade Marathon in 2028.

Men accounted for $87.7 \%$ and women $12.3 \%$ of all the persons who ran the Belgrade Marathon in the period from 2007 to 2019. Among the participants from Serbia there were even fewer women: only $10.5 \%$. It can be said that the number of women inthe Belgrade Marathon is relatively far lower than in countries with a longer tradition of long-distance running, and a far greater number of participants in marathon races. Women accounted for $10.5 \%$ of all the people who ran a marathon in the US in 1980, but their number increased to $40 \%$ in 2007 (Hoffman \& Wegelin, 2009).

It is encouraging that the number of women is growing faster than the number of men every year, especially on the sample of participants from Serbia. For the participants from Serbia in the first years in the studied period, there were about 20 men to each woman who ran the marathon, while in 2019 a record number of women was recorded in both absolute numbers (87) and percentages (14.2\%) and the ratio of numbers of men to the number of women (6.02: 1). A relatively higher increase in the number of women than men was also observed for the New York City Marathon, where the ratio of men to women decreased from 5.6: 1 to 2.47: 1 from 1983-1999 (Jokl, Sethi \& Cooper, 2004), from 5.1: 1 in the decade 1980-89 to 2.1: 1 in the decade 2000-2009 (Lepers \& Cattagni, 2012). The number of women inthe 2017 Chicago Marathon was as high as 1.06: 1 (Chicago Marathon results, 2007) and inthe 2018 New York Marathon 1.38: 1 (TCS New York City Marathon, 2018), but the women were far more numerous than the men in the 20-29 age category (1.28: 1 in favor of women).

If such trends continue, it is not unrealistic to expect that there will be more women running themarathon than men at some major world marathon soon.

\section{Participants from Serbia in the Belgrade Marathon from 2007 to 2019by sex and age}

The youngest participants from Serbia who completed the Belgrade Marathon in the period from 2007 to 2019, they were 17 years old for men (3 participants in 2019), or 18 for women. The oldest men who ran the marathon in this period were over 80 , and the oldest women over 60 . The majority of participants among both men and women were in the 30-34 age category. When looking at age categories of ten, the largest number of men and women ranged in age from 30-39, which is identical to the 2006 and 2007 New York City marathon participants, as well as to all US runners since 2000-2007 (Hoffman \& Wegelin, 2009). Similar results are reported for the Stockholm Marathon, 1979-2014, where the number of male participants by age category increased to 40 and then declined slightly (Lehto, 2016). However, in recent years, the number of older participants appears to be increasing to a greater extent than in the younger ones. The largest number of finishers in the New York marathon in 2018 belonged to the 40-49 age group $(16,176)$, slightly fewer were 30-39-year-olds $(15,659)$, while there were far fewer participants (less than 10,000) in all the other age groups(TCS New York City Marathon, 2018).

A linear regression analysis of the ratio of the number of men to the number of women participating in the Belgrade Marathon, in age categories of 5 years, showed that the number of women in the older categories decreased significantly faster than the men $(\mathrm{p}<0.05)$, which is especially pronounced in the categories over 55 years of age. These results are in contrast to what was recorded at the New York Marathon 1980-2010, where 
the relative number of women increased faster than the number of men (as well as at the Belgrade Marathon), but this increase was more pronounced in the older categories (Hunter \& Stevens, 2013). Also, in the Jungfrau Marathon, 2000-14, the percentage of women relative to the number of men increased in all age categories from 30-69 (except in the 55-59 category) (Knechtle, Rosemann, Zingg, \& Rüst, 2015).

A positive trend in the number of marathon participants from Serbia is also observed in all age categories of men and women. Highly reliable linear regression models show that the number of women and men at the Belgrade Marathon, in all age categories, has increased statistically significantly over the period from 2007 to 2019. These results are better than the trends at the two marathons in Switzerland. In the period from 2000 to 2014, at the famous Jungfrau Mountain Marathon (start at 565m and target at 2095m altitude), there was an increase in the number of women in all ages except the youngest (under 25), while in men the number of participants increases in most age categories (except in categories 30-34, 40-44 and 55-59, where unchanged). During the same period, the Lausanne City Marathon increased the number of women only in the 30-34 and 40-44 age categories, and in the men in the 25-29, 40-44 and 55-59 age categories (Knechtle et al. 2015).

When the number of participants in each age category is expressed, as a percentage of the total number of participants, the situation is slightly different. The linear regression models show that in the period from 2007 to 2019, the percentage of men and women in the 30-39 age category increases statistically significant, and the percentage of men in the 50-59 age category decreases statistically significant. The results obtained are different from those recorded at the New York Marathon from 1983 to 1989, with the largest increase in the number of men and women in all categories over 50 (Jokl et al., 2004).

Models of linear regression of seniors and veterans from Serbia showed that in absolute values the number of seniors and veterans among men and women increases statistically significant, but that only the percentage of women seniors and women veterans increases statistically significant, and that the percentage of male veterans is statistically significant. The results obtained are only partially in accordance with the results of the New York City Marathon survey (Lepers \& Cattagni, 2012). Namely, both marathons show a higher increase in the number of women, but in New York there is a relatively higher increase in the number of veteran men than the seniors, while in Belgrade the percentage of male veterans is decreasing.

\section{CONCLUSION}

It can be concluded that the number of participants in the Belgrade Marathon, and in particular the number of participants from Serbia, is increasing significantly. Based on this research, it was determined that there is a trend inthe Belgrade Marathon that is higher than in other world-famous marathons whose results were used in comparison with the Belgrade Marathon. The number of women in the Belgrade Marathon is lower than in most marathons in the world, but the number of women from Serbia is increasing significantly compared to the number of men, which is in line with world trends. The percentage of male veterans is decreasing, which is different from most marathons in the world.

Presenting the results from the Belgrade Marathon in the period from 2007 to 2019 will enable the creation of a more precise "picture of the situation" from this event, the possibility of monitoring the changes that took place in the analyzed period and the 
possibility of predicting the number of participants from abroad and Serbia if trends, such as in the period from 2007 to 2019 , continue.

Acknowledgments. This paper is part of the research within the project "Cellular and molecular basis of malignant and cardiovascular diseases - clinical implications”, No. III41027, funded by the Ministry of Science and Technological Development of the Republic of Serbia - Extended cycle of scientific projects 2011-2018.

\section{REFERENCES}

Ahmadyar, B., Rüst, C.A., Rosemann, T., \& Knechtle, B. (2015). Participation and performance trendsin elderly marathoners in four of the world's largest marathons during 2004-2011. Springer Plus, 4, 465

Beogradski maraton deo World marathon Majors serije (2019). Beogradski marathon (Belgrade Marathon). Retrieved July 24, 2019 from the World Wide Web:

http://www.bgdmarathon.org/v/a328fa50-4bb7-4872-b61a-e4eef975c719/33-Beogradski-maraton-deo-Worldmarathon-Majors-Serije.aspx. In Serbian

Burfoot, A. (2007). The history of the marathon. Sports Medicine, 37 (4-5), 284-287.

Chicago Marathon Results (2007). Chicago: Marathon Guide.com. Retrieved July 21, 2019 from the World Wide Web: http://www.marathonguide.com/results/browse.cfm?MIDD=67071007.

Coyle, E.F. (2007). Physiological regulation of marathon performance. Sports Medicine, 37(4-5), 306-311.

Hespanhol Junior, L.C., Pillay, J.D., van Mechelen, W., \& Verhagen, E. (2015). Meta-analyses of the effects of habitual running on indices of health in physically inactive adults. Sports Medicine, 45, 1455-1468.

Hoffman, M.D., \& Wegelin, J.A. (2009). The western states 100-mile endurance run: Participation andperformance trends.Medicine \& Science in Sports \& Exercise, 41(12), 2191-2198.

Hunter, S., \& Stevens, A. (2013). Sex differences in marathon running with advanced age: Physiology or participation? Medicine \& Science in Sports \& Exercise. 45(1), 148-156.

Jokl, P., Sethi, P.M.,\&Cooper, A.J. (2004). Master's performance in the New York City Marathon 1983-1999. British Journal of Sports Medicine, 38(4), 408-412.

Juhas, I., \& Repić-Ćujić, V. (2016). Maraton za žene u Srbiji (Marathon for women in Serbia). Belgrade: University of Belgrade, Faculty of Sport and Physical Education. In Serbian

Knechtle, B., Rosemann, T., Zingg, M.A., \&Rüst, C.A. (2015). Increase in participation but decrease in performance in age group mountain marathoners in the 'Jungfrau Marathon': a Swiss phenomenon? Springer Plus, 4:523

Knechtle, B., Di Gangi, S., Rüst, C., \& Nikolaidis, P. (2019). Performance differences between the sexes in the Boston Marathon from 1972 to 2017. Journal of Strength and Conditioning Research, DOI: 10.1519/JSC. 0000000000002760

Lee, D.C., Pate, R.R., Lavie, C.J., Sui, X., Church, T.S., \& Blair, S.N. (2014). Leisure-time running reduces all-cause and cardiovascular mortality risk. Journal of the American College of Cardiology, 64(5), 472-481.

Lehto, N. (2016). Effects of age on marathon finishing time among male amateur runners inStockholm Marathon 1979-2014. Journal of Sport and Health Science, 5, 349-354.

Lepers, R., \& Cattagni, T. (2012). Do older athletes reach limits in their performance duringmarathon running? Age, 34, 773-781.

Leyk, D., Rüther, T., Wunderlich, M., Sievert, A., Essfeld, D., Witzki, A., et al. (2010). Physical performance in middle age and old age: good news for our sedentary and aging society. Deutsches Ärzteblatt International, 107, 809-816.

Leyk, D., Erley, O., Gorges, W., Ridder, D., Rüther, T., Wunderlich, M., et al. (2009).Performance, training and lifestyle parameters of marathon runners aged 20-80 years: Results of the PACE-study. International Journal of Sports Medicine, 30(5), 360-365.

Milutinović, K., Stojiljković, S., Ćuk, J., Lasica, R., Miosavljević, A., Cvetković, D., et al. (2018). Athlete’s heart.Physical Culture, 72(2), 135-147.

Mitić, D., \&Stojiljković, S. (1992). Lična karta učesnika beogradskog maratona (Identity card of participants of the Belgrade Marathon). Godišnjak Fakulteta fizičke kulture Univerziteta u Beogradu, 4, 167-174. In Serbian

Mustedanagić, J., Bratić, M., Milanović, Z., \&Pantelić, S. (2016). The effect of aerobic exercise program on the cardiorespiratory fitness and body composition of female college students. Facta Universitatis Series Physical Education and Sport, 14(2), 145-158.

Nikolaidis, P.T., Rosemann, T., \& Knechtle, B. (2018a). Sex differences in the age of peak marathon race time.Chinese Journal of Physiology, 61, 85-91. 
Nikolaidis, P.T., Rosemann, T., \& Knechtle, B. (2018b). A brief review of personality in marathon runners: The role of sex, age and performance level. Sports, 6, 99.

Noakes, T.D. (2003). Lore of running, fourth edition. Human Kinetics, Champaign, IL.

Rasmussen, C.H., Nielsen, R.O., Juul, M.S., \& Rasmussen, S. (2013). Weekly running volume and risk of runningrelated injuries among marathon runners. The International Journal of Sports Physical Therapy, 8(2), 111-120.

Stojiljković, S. (2005). Efekti trčanja u različitim zonama intenziteta (Effects of running in different intensity zones). Monograph, Library Special Issues, Zadužbina Andrejević, Belgrade. In Serbian

Stojiljković, S., Mitić, D., Mandarić, S., \& Nešić, D. (2012). Personalni fitness (Personal fitness). Belgrade: University of Belgrade, Faculty of Sport and Physical Education. In Serbian

TCS New York City Marathon (2018). NYRR Race Results. Retrieved July 21, 2019 from the World Wide Web: https://results.nyrr.org/event/M2018/finishers.

Trappe, S. (2007). Marathon runners: How do they age? Sports Medicine, 37 (4-5), 302-305.

Vitti, A., Nikolaidis, P.T., Villiger, E., Onywera, V., \& Knechtle, B. (2019). The "New York City Marathon": participation and performance trends of $1.2 \mathrm{M}$ runners during half-century. Research in Sports Medicine, DOI: $10.1080 / 15438627.2019 .1586705$

World Health Organization-WHO (2009). Global health risks: Mortality and burden of disease attributable to selected major risks. World Health Organization, Geneva.

Williams, P.T. (2009). Incident hypercholesterolemia in relation to changes in vigorous physical activity. Medicine \& Science in Sports \& Exercise, 41, 74-80.

Zabala, E.L., Rueda, M.C.P.L., de la Llave Rodríguez, A.L. (2009). Characteristics of the psychological state of popular marathon runners. Revista de Psicologia del Deporte, 18, 151-163.

\section{TREND BROJA UČESNIKA IZ SRBIJE NA BEOGRADSKOM MARATONU OD 2007 DO 2019-TE GODINE: EFEKAT POLA I GODINA}

Cilj istraživanja je analiza trenda broja učesnika Beogradskog maratona u periodu od 2007-2019: ukupno, po polu i starosnim kategorijama, sa posebnim osvrtom na učesnike iz Srbije. Pomoću linearnih regresija je utvrđeno da se značajno povećava: ukupan broj učesnika, $i$ onih iz Srbije i iz inostranstva; ukupan broj muških $i$ ženskih učesnika; broj žena iz godine u godinu raste više nego broj muškaraca, naročito na poduzorku učesnika iz Srbije; broj učesnika po starosnim kategorijama od 5 godina, kod žena i muškaraca iz Srbije raste do starosne kategorije 30-35 godina, a zatim polako opada; raste procenat muškaraca $i$ žena u kategoriji 30-39 godina; raste procenat žena seniora i žena veterana. Statistički značajnoopada: procenat muškaraca u kategoriji 50-59 godina; procenat muškaraca veterana. Procenat muškaraca seniora se ne menja. Može se zaključiti da broj učesnika Beogradskog maratona, naročito učesnika iz Srbije, statistički značajno raste, sa trendom koji prevazilazi mnoge maratone u svetu. Broj žena je manji nego na većini maratona u svetu, ali se broj žena iz Srbije statistički značajno povećava u odnosu na broj muškaraca, što je u skladu sa svetskim trendovima. Broj muškaraca veterana se procentualno smanjuje, što se razlikuje od većine maratona u svetu.

Ključne reči: trčanje, polne razlike, regresioni modeli 